\author{
Kostiantyn Tkachenko ${ }^{1}$, Olha Tkachenko ${ }^{2 *}$, Oleksandr Tkachenko $^{3}$ \\ ${ }^{1}$ Information Technologies and Design Department, State University of Infrastructure and Technologies, 9, \\ Kyrylivska str., Kyiv, 04071, Ukraine. ORCID: https://orcid.org/0000-0003-0549-3396 \\ ${ }_{2}^{2}$ Information Technologies and Design Department, State University of Infrastructure and Technologies, 9, \\ Kyrylivska str., Kyiv, 04071, Ukraine. ORCID: https://orcid.org/0000-0003-1800-618X \\ ${ }^{3}$ Software Engineering Department, National Aviation University, 1, Liubomyra Huzara ave., Kyiv, 03058, \\ Ukraine. ORCID: http://orcid.org/0000-0001-6911-2770
}

*Corresponding author: oitkachen@gmail.com

\title{
MODELING OF SYSTEM FOR MONITORING OF RISKS IN THE TRANSPORT
}

The article deals with the actual problems of modeling the processes for monitoring risks in transport. This monitoring involves determining the state of transport objects, as well as procedures for minimizing the consequences of situations caused by the onset of risks. The article discusses the problems of effective creation of system for monitoring of risks in transport based on the use of appropriate models. The article proposes modeling this system based on situational-semantic model. The approach proposed would contribute to recognition of risks and generation of management decisions to eliminate their consequences. The proposed situational-semantic model allows: to predict the behavior of complex transport objects and transport infrastructure objects; take into account the possibility of emergence of new transport objects and processes for ensuring their functioning in conditions of minimizing possible risks; respond adequately to local and global factors of influence on transport objects; dynamically change the structure of the system; take into account new data to predict the development and improvement of relevant transport objects; predict the development of processes to ensure minimization of risks and the consequences of them.

Keywords: model, modeling, information system, transport risks, monitoring of processes, semantic measures, situational-semantic measures.

Introduction. Transport is always associated with certain risks. Studying these risks, determining the degree of their impact on the functioning of transport objects and transport infrastructure objects is a complex problem. This is due to the fact that, firstly, there are several classes of risks in transport, in particular:

Technical risks: production, technological, innovative.

Economical risks: property, commercial, financial, credit and interest rate.

Social risks.

Environmental risks.

And, secondly, each of the risks is associated with a large number of dynamically changing factors of influence. Therefore, the monitoring of risks, the development of appropriate information systems is an important and urgent problem. The creation of such complex systems will be optimal if it is based on the use of models of objects and processes in transport.

Modeling of risk monitoring systems in transport would facilitate the timely recognition of risks and the generation of solutions to eliminate their consequences.

Analysis of recent research and problem statement. When building a complex technical system, which is a system for monitoring of risks in the transport [1 - 4], it is important to choose the method 
of presenting knowledge about the subject area (transport industry). Among the main types of models of knowledge representation should be noted [5-8]:

1) production model - a model based on rules, allowing to present knowledge in the form of proposals such as: "If a condition, then an action";

2) semantic network - an oriented graph in which concepts and objects are represented as vertices, and relations between objects are represented as arcs;

3) frame model - a model based on frames, which consist of a finite number of slots, each of which has a name and meaning.

4) ontological model - a conceptual construction based on some global categories (space, time and quality).

The construction of an intelligent safety management system for complex transport complexes is considered in [9]. In [10], a multilevel model of an object-oriented intelligent system is proposed. The principles of designing complex systems are considered in [11].

These works do not consider the case when objects are dynamic, can function under conditions of certainty and knowledge about objects is heterogeneous. This can lead to incorrect risk assessment, as well as to an erroneous assessment of the feasibility of the operation of the transport objects or transports infrastructure objects. Therefore, the problem of developing a model of system for monitoring of risks in the transport is relevant.

The purpose and tasks of the study. In this work, when modeling of system for monitoring of risks in the transport, a systematic approach was used, as well as analysis methods and a classification method.

The main goal of this work is to develop a model of the system for monitoring of risks in the transport. As such a model, a situational-semantic model was proposed [12].

Materials and methods of research. Modeling of system for monitoring of risks in the transport (transport objects and processes for ensuring their safe operation without risks) can be based on different models, the choice of which is determined by the tasks set (in our case, this is minimizing the consequences of existing risks or minimizing the chances of their occurrence) and the subject area ( transport industry).

The authors propose to use modeling based on a multi-level model of a special class of semantic networks (SM) - situational-semantic networks (SSM), in which situations determine not only the description of the model at any of its levels, but also the transition from one level to another [13].

The SM that is used is a system of knowledge of the subject area (the transport industry, its individual components: transport objects and transport infrastructure objects (bridges, train stations, hotels, etc.).

This has a certain content in the form of a coherent image of a specific network model of the system for monitoring of risks in the transport.

The nodes of this model correspond to transport objects or transport infrastructure objects (concepts of the subject area, system components, constituent elements of the process of ensuring the functioning of a transport objects or transport infrastructure objects (either with minimal risk (economical, technical, environmental, social), or with the presence of minimization procedures the consequences of the onset of risks).

Arcs reflect the relationship between all objects of the considered domain.

Formalization of the SM is possible provided it is systematized.

For example, in the model, the functions of relations between concepts are systematized using the following features:

relationships (for example, "abstract - concrete", "whole - part", "cause - effect");

conditions for the application of relations;

links (conjunctive, disjunctive, exclusive OR).

SM can be given by three:

$\mathrm{M}_{\mathrm{sm}}=\left\{\mathrm{G}_{\mathrm{sm}}, \mathrm{H}_{\mathrm{sm}}, \mathrm{U}_{\mathrm{sm}}\right\}$,

where $\mathrm{G}_{\mathrm{sm}}-$ set of elementary transport object and transport infrastructure object (nodes), $\mathrm{G}_{\mathrm{sm}} \neq \varnothing$; 
$\mathrm{H}_{\mathrm{sm}}$ - set of connections between nodes (arcs), $\mathrm{H}_{\mathrm{sm}} \subseteq\left(\mathrm{G}_{\mathrm{sm}} \cup \mathrm{G}_{\mathrm{sm}}\right)$;

$\operatorname{dom}\left(\mathrm{H}_{\mathrm{sm}}\right) \cup \operatorname{ran}\left(\mathrm{H}_{\mathrm{sm}}\right)=\mathrm{G}_{\mathrm{sm}}$,

where $\operatorname{dom}\left(\mathrm{H}_{\mathrm{sm}}\right)=\left\{\mathrm{y} \in \mathrm{G}_{\mathrm{sm}} \mid \exists \mathrm{x} \in \mathrm{G}_{\mathrm{sm}},(\mathrm{x}, \mathrm{y}) \in \mathrm{H}_{\mathrm{sm}}\right\}, \operatorname{ran}\left(\mathrm{H}_{\mathrm{sm}}\right)=\left\{\mathrm{y} \in \mathrm{G}_{\mathrm{sm}} \mid \exists \mathrm{x} \in \mathrm{G}_{\mathrm{sm}},(\mathrm{x}, \mathrm{y}) \in \mathrm{H}_{\mathrm{sm}}\right\}$, that is, any SM node is incident to at least one SM node.

Usm - set of loads on elements from a set Hsm. Gsm $=\{$ Gssm i $\}$, where

$\mathrm{G}_{\mathrm{smi}}^{\mathrm{s}}$ - i-th node $\mathrm{SM}$,

$\mathrm{H}_{\mathrm{sm}}=\left\{\mathrm{H}_{\mathrm{smj}}^{\mathrm{s}}\right\}$, where $\mathrm{H}_{\mathrm{sm} j}^{\mathrm{s}}-\mathrm{j}$-th arc,

$\mathrm{U}_{\mathrm{sm}}=\left\{\mathrm{U}_{\mathrm{sm} \mathrm{jk}}^{\mathrm{s}}\right\}$, where $\mathrm{U}_{\mathrm{sm} \mathrm{jk}}^{\mathrm{s}}-\mathrm{k}$-th load on the $\mathrm{j}$-th arc of the SM.

When constructing a SM, the number of elements and their connections is not limited, and the systematization of relations between objects (transport and transport infrastructure) of the network is necessary for the subsequent formalization of the processes of monitoring risks in transport.

Systematization of SM relations is a complex problem and depends not only on specific transport objects or transport infrastructure objects, but also on the processes occurring in them and possible risks both as a result of their functioning and for their functioning.

In particular, it depends on the processes of ensuring the functioning of transport objects and transport infrastructure objects without economical, technical, environmental and social risks and monitoring these risks.

When systematizing SM relations, an important role is played by the hierarchy of relations between objects, which can be divided into:

generally valid (characteristic of almost all objects),

significant (characteristic of many objects),

specific (characteristic of individual objects).

Objects are understood as transport objects and/or transport infrastructure objects.

There are the following types of SM [14]:

1. Logical-semantic, describing a transport object in terms of the subject area (in our case, the transport industry), including all consistent statements and facts.

2. Structural and functional, considering a transport object or a transport infrastructure object) as integral, dividing it into separate important elements.

3. Cause-and-effect, used to describe the dynamics of complex processes of ensuring the functioning of transport objects and transport infrastructure objects safely or with minimal risks (economical, technical, environmental, social).

The authors propose an SSM, which also takes into account the situational monitoring of the risks of transport objects and transport infrastructure objects.

All situations, according to which modeling of the system for monitoring of risks in the transport is carried out, can be divided into:

regular,

non-standard.

Standard situations can be divided into:

generally significant,

significant,

specific.

The use of situations and their typification contributes to the multilevel structure of the proposed model (SSM) of system for monitoring of risks in the transport.

Formally, the SSM can be set as follows:

$\mathrm{M}_{\mathrm{ssm}}=\left\{\mathrm{G}_{\mathrm{ssm}}, \mathrm{H}_{\mathrm{ssm}}, \mathrm{U}_{\mathrm{ssm}}, \mathrm{S}_{\mathrm{ssm}}\right\}$,

where $\mathrm{G}_{\mathrm{ssm}}$ - set of transport objects and transport infrastructure objects (nodes), $\mathrm{G}_{\mathrm{ssm}} \neq \varnothing$;

$\mathrm{H}_{\mathrm{ssm}}$ - set of connections between nodes ( $\left.\operatorname{arcs}\right), \mathrm{H}_{\mathrm{ssm}} \subseteq\left(\mathrm{G}_{\mathrm{ssm}} \cup \mathrm{G}_{\mathrm{ssm}}\right)$;

$\operatorname{dom}\left(\mathrm{H}_{\mathrm{ssm}}\right) \cup \operatorname{ran}\left(\mathrm{H}_{\mathrm{ssm}}\right)=\mathrm{G}_{\mathrm{ssm}}$,

where $\operatorname{dom}\left(\mathrm{H}_{\mathrm{ssm}}\right)=\left\{\mathrm{y} \in \mathrm{G}_{\mathrm{ssm}} \mid \exists \mathrm{x} \in \mathrm{G}_{\mathrm{ssm}},(\mathrm{x}, \mathrm{y}) \in \mathrm{H}_{\mathrm{ssm}}\right\}, \operatorname{ran}\left(\mathrm{H}_{\mathrm{ssm}}\right)=\left\{\mathrm{y} \in \mathrm{G}_{\mathrm{ssm}} \mid \exists \mathrm{x} \in \mathrm{G}_{\mathrm{ssm}},(\mathrm{x}, \mathrm{y}) \in\right.$

$\left.\mathrm{H}_{\mathrm{ssm}}\right\}$, that is, any SSM node is incident to at least one SSM node;

$\mathrm{U}_{\mathrm{ssm}}-$ set of loads on elements $\mathrm{H}_{\mathrm{ssm}}$; 
$\mathrm{S}_{\mathrm{ssm}}-$ set of situations in which functioning occurs SSM.

$\mathrm{G}_{\mathrm{ssm}}=\left\{\mathrm{G}_{\mathrm{ssm} \text { i }}^{\mathrm{s}}\right\}$, where:

$\mathrm{G}_{\mathrm{ssm} \text { i }}^{\mathrm{s}}$ - i-th node SSM;

$\mathrm{H}_{\mathrm{ssm}}=\left\{\mathrm{H}_{\mathrm{ssm} j}^{\mathrm{s}}\right\}$, where $\mathrm{H}_{\mathrm{ssm} j}^{\mathrm{s}} \mathrm{j}-\mathrm{j}$-th $\operatorname{arc} \mathrm{SSM}$;

$\mathrm{U}_{\mathrm{ssm}}=\left\{\mathrm{U}_{\mathrm{ssm}}^{\mathrm{s}} \mathrm{j}\right\}$, where $\mathrm{U}_{\mathrm{ssm}}^{\mathrm{s}} \mathrm{j}-\mathrm{j}$-th load on the $\mathrm{j}$-th $\operatorname{arc} \mathrm{SSM}$;

$\mathrm{S}_{\mathrm{ssm}}=\left\{\mathrm{S}_{\mathrm{ssm}}^{\mathrm{s}} \mathrm{i}\right.$, where $\mathrm{S}_{\mathrm{ssm} \mathrm{i}}^{\mathrm{s}}$ - situation that determines the semantics of the i-th node SSM.

Route (path) - a sequence of nodes $\mathrm{x}_{1}, \ldots, \mathrm{x}_{\mathrm{k}}$ of the network $\mathrm{M}_{\mathrm{ssm}}$ such that

$\mathrm{P}_{\mathrm{ssm} 1 \mathrm{k}}=\left\{\left(\mathrm{x}_{1}, \mathrm{x}_{2}\right), \ldots,\left(\mathrm{x}_{\mathrm{k}-1}, \mathrm{x}_{\mathrm{k}}\right)\right\} \in \mathrm{H}_{\mathrm{ssm}} \mathrm{xH}_{\mathrm{ssm}}$.

Path $P_{\text {ssm } 1 k}=\left\{x_{1}, \ldots, x_{k}\right\}$ leads from node $x_{1}$ to the node $x_{k}$.

Route (path) $\mathrm{P}_{\mathrm{ssm} x \mathrm{x}}$ from node $\mathbf{x}$ to the node $\mathbf{y}$ is a cycle, if none of the nodes appears in it more than once, the $\operatorname{arc}(\mathrm{x}, \mathrm{y}) \in \mathrm{H}_{\mathrm{ssm}}$ and its beginning $\mathbf{x}$ coincides with its end $\mathbf{y}$.

Analysis of the results of the execution of the model (SMM) provides for reporting the situations in which the transport object was (or was not) (the process of ensuring the security of the transport object). Monitoring is carried out which situations for the object (transport or transport infrastructure) are unattainable and impossible.

Analysis of the functioning of a transport object based on the SSM provides quantitative and qualitative characteristics of its states. If deficiencies are found in the SSM, then the model is modified several times until a model is obtained that is adequate to the transport object.

SSM components and their actions act as events. Examples of events can be, in particular: situational determination of the route on the SSM, according to which the values of the criteria that determine the situation are calculated.

Each event can happen once, many times, or never happen. This means that the event is blocked and will not be implemented until the appropriate conditions are met.

The situational nature of the model is determined by the functioning of transport objects and the corresponding class of tasks.

In order for an event with respect to a transport object or a transport infrastructure object (the process of ensuring the functioning of a transport object or a transport infrastructure object without risks (economic, including economical, technical, environmental, social)) to take place, situations must arise in which this event can be implemented.

Situation - a set of conditions for the occurrence of an event.

The event is implemented if the conditions for its implementation are met.

The condition can be unfulfilled (its capacity is zero), fulfilled (its capacity is equal to one), fulfilled with an $\mathrm{n}$-fold margin (its capacity is $\mathrm{n}$, where $\mathrm{n}$ is a natural number).

Indicators of quantitative assessment of the SSM: connectivity, reachability, redundancy, compactness. Connectivity index $\gamma_{\mathrm{c}}$ for SSM with n nodes:

$$
\gamma_{\mathrm{c}}=\frac{1}{\mathrm{n}-1} \sum_{i=1}^{n} \sum_{j=1}^{n} a_{i j}^{(c)}
$$

Indicator of redundancy $\alpha=\gamma_{c}-1$.

Indicator of reachability $\delta_{\mathrm{r}}=\frac{1}{\mathrm{n}^{2}} \sum_{i=1}^{n} \sum_{j=1}^{n} a_{i j}^{(d)}$.

Indicator of compactness $\mathrm{C}_{\mathrm{omp}}=\sum_{i=1}^{n} \sum_{j=1}^{n} a_{i j}^{(p)}$.

$a_{i j}^{(c)}, a_{i j}^{d}, a_{i j}^{p}$ - elements of the corresponding adjacency, reachability and distance matrices.

The SSM of the system for monitoring of risks in the transport should be:

reliable; adequate;

purposeful;

simple and understandable for the user; 
complete; reliable;

such that it assumes the possibility of modification.

To adequately reflect the connection between input and output in the SSM, the concepts "state" and "situation" are used.

The state $\mathrm{z}\left(\mathrm{t}_{\mathrm{i}}\right)$ is a set of properties (states, situations) of the SSM, the knowledge of which at the moment of time $t_{i}$ allows us to determine its behavior at the moments of time $t>t_{i}$.

Modeling of system for monitoring of risks in the transport, processes for ensuring the functioning of transport objects and transport infrastructure objects in conditions of minimizing risks and/or eliminating their consequences should begin with:

descriptions of all elements of the model of;

determining the content of these components and areas of change.

For the full functioning of the system for monitoring of risks in the transport, it is necessary to determine:

the time interval in which the SSM of the system for monitoring of risks in the transport operates;

input and output impacts on possible risks (economical, technical, environmental, social) and areas of their possible changes;

the set of characteristics of the state of the subject area (and / or its individual objects) and the area of their possible changes.

Note that within the framework of one SSM, several variants of its submodels can be built (depending on situations, factors of influence, criteria for assessing risks, etc.) The constructed model reflects expert knowledge about possible risks in transport, the reasons for their occurrence and and ways of their elimination or minimization.

There are two approaches to constructing an SSM [15].

1. «From above». At the initial stage, the core of the SSM is built, which is further completed with the help of separate blocks of the model. Individual components of the model can be dynamically completed to the core of the SSM.

2. «From below». At the initial stage, the core of the SSM is built, which is further completed with the help of separate blocks of the model.

The model allows you to:

clear cognitive analysis,

dynamic modeling,

forecasting trends in the development of the transport system and its individual subsystems

(individual transport objects and transport infrastructure objects),

forecasting the quantitative values of the criteria characterizing the risks in transport;

analysis of model cycles, including life cycles; - analysis of the stability of the process,

analysis of structural resistance to disturbing and control influences,

topological analysis of the structure of the model.

Topological analysis, calculation of system indicators of transport objects and transport infrastructure objects can also be carried out for the SSM.

The formation of control actions involves the implementation of the adjustment of the SSM.

A model correction is understood as:

changing the structure of the model (adding or removing any objects, factors and relationships (connections) between them),

change in values characterizing objects, factors and connections.

Users are prompted to make one of the following decisions:

make adjustments to the initial SSM;

to develop a new SSM.

Let's consider an example of risk assessment.

To build the SSM of the system for monitoring of risks in the transport, the factors necessary for assessing risks, the relationship between them, and their significance were identified. 
At subsequent stages, when constructing an SSM, factors that characterize the individuality of transport objects and transport infrastructure objects can be used.

The values of the connections between the vertices are assigned based on expert knowledge (their opinions, judgments, forecasts, etc.). The judgments were obtained by interviewing experts in the subject area under consideration - the transport industry.

Figure 1 shows the risk assessment model using the principle «from below».

Here:

$\mathrm{v} 1$ is the number of tasks;

$\mathrm{v} 2$ - the speed of execution of work to eliminate the consequences caused by the risks;

$\mathrm{v} 3$ is the number of expert assessments of risks and their consequences;

$\mathrm{v} 4$ - the onset of a situation caused by the emergence of a risk;

v5 - minimization of economic risks;

v6 - system reliability,

v7 - the ability of transport objects and objects of the transport system to function without the manifestation of negative environmental consequences;

v8 - external factors affecting transport objects and transport infrastructure objects;

$\mathrm{v} 9$ - the number of errors made by users of the system;

$\mathrm{v} 10$ is the time taken to create the system; v11 - financial costs for creating the system;

$\mathrm{v} 12$ is the number of system users;

v13 - qualification of system users;

v14 - violation of normal operation;

v15-emergency.

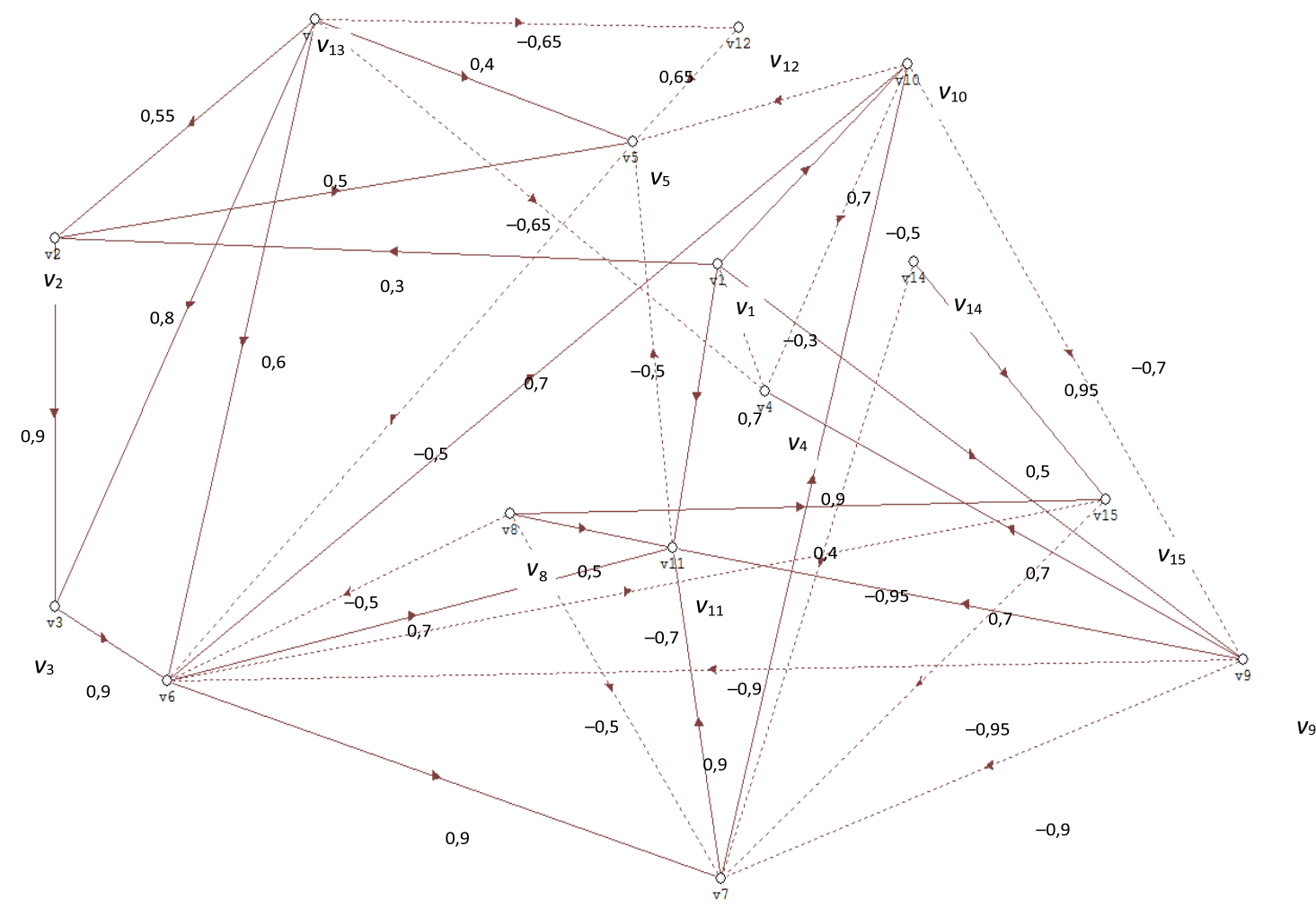

$v_{7}$

Fig. 1. Risk Assessment Model

(Source: designed by the authors) 
The relationships shown in Figure 1 can be interpreted as follows:

for example, the relationship $\mathrm{v} 3 \rightarrow \mathrm{v} 6$ with a weight of 0.9 means that if the value of the parameter of the vertex v3 increases (decreases) by $10 \%$, then the value of the parameter of the vertex v6 increases (decreases) (sign "+") by $9 \%$;

the relationship v10 $\rightarrow$ v9 with a weight of -0.7 means that if the value of the vertex parameter v10 decreases by $10 \%$, then the value of the vertex parameter v9 will increase (" $-"$ sign) by $7 \%$.

Conclusions. The proposed model (SSM) of system for monitoring of risks in the transport:

allows predicting of the behavior of complex transport objects and transport infrastructure objects in the context of monitoring possible risks;

takes into account (due to its dynamism) the possibility of the emergence of a new type of transport objects (and transport infrastructure objects) and processes for ensuring their functioning in conditions of minimizing possible risks;

responds adequately to local and global factors of influence on transport objects and transport infrastructure objects;

dynamically changes its structure;

allows you to take into account new data for more accurate forecasting of the development and improvement of the relevant transport objects and transport infrastructure objects;

allows predicting of the development and improvement of processes to ensure minimization of risks, their complete absence or elimination and minimization of consequences due to the onset of situations caused by the emergence of risks.

\section{REFERENCES}

1. Yurkov N.K. (2013). System approach to the organization of life cycle of complex technical systems. Reliability and quality of difficult systems: Scientific and practical. 2013(1), 27 - 35. [In Russian].

2. Lipaev V.V. (2010). The problems of software engineering: quality, safety, risk, economy [In Russian]. Software engineering. 2010(1), 7-20. [In Russian].

3. Info TS 08/17Compliance and Risk Monitoring of Transport Operations through Auditing. https://www.eiga.eu/publications/safety-informations-transport/info-ts-0817-compliance-and-risk-monitoring-of-transportoperations-through-auditing/

4. Staznik A., Babich D., Bajo I. (2017). Identification and analysis of risks in transport chains.Istrazivanja i Projektovanja za Privredu. 15(1), 61-70. DOI: https://doi.org/10.5937/jaes15-12179

5. Nechaev V.V, Koshkarev MI. (2015). Architecture of object-oriented knowledge base intelligent systems. Educational resources and technology. 2015(1), 156-163. [In Russian].

6. Adema J. (2015). New Models of Knowledge Production. Open Access Publishing and Experimental Research Practices (Part III). https://openreflections.wordpress.com/2015/02/27/new-models-of-knowledge-production-open-accesspublishing-and-experimental-research-practices-part-iii/

7. Types of Knowledge Representation (2021). https://www.brainkart.com/article/Types-of-KnowledgeRepresentation_8892/

8. How Important Are Semantic Networks In Artificial Intelligence (2019). https://analyticsindiamag.com/semanticnetworks-ai/

9. Kolodenkova A.E. (2016). The process modeling of project feasibility for information management systems using the fuzzy cognitive models. Herald of computer and information technologies 2016(6), 10-17. [In Russian].

10. Gorelova G.V.. (2018). A cognitive approach for modeling of complex systems. News of SFU. Technical science. 2018(3), 239-250. [In Russian].

11. Tkachenko O., Tkachenko K., Tkachenko O. (2020). Designing complex intelligent systems on the basis of ontological models. Proceedings of The Third International Workshop on Computer Modeling and Intelligent Systems (CMIS-2020). 266-277.

12. Tkachenko O., Tkachenko O. (2017). Some aspects of situation-semantic modeling of complex objects, processes and systems. Water transport. 2017(1), 129-133.

13. Bellinger G., Castro D., Mills A. (2016). Data, Information, Knowledge, and Wisdom. http://www.outsights.com/systems/dikw/dikw.htm.

14. Futia G. (2020). Semantic Models for Constructing Knowledge Graphs. https://towardsdatascience.com/semanticmodels-for-constructing-knowledge-graphs-38c0a1df316a.

15. Dodonov A.G., Lande D.V, Berezin B.A. (2018). A method of semantic models for constructing and using for the public opinion monitoring. Registration, storage and data processing. 20(4), 53-63. [In Ukrainian]. 


\section{Костянтин Ткаченко ${ }^{1}$, Ольга Ткаченко ${ }^{1}$, Олександр Ткаченко ${ }^{2}$}

1 Кафедра інформаційних технологій та дизайну, Державний університет інфраструктури та технологій, вул. Кирилівська, 9, м. Київ, 04071, Україна

${ }^{2}$ Кафедра інженерії програмного забезпечення, Національний авіаційний університет, вул. Любомира Гузара,1, м. Київ, 03058, Україна

\section{МОДЕЛЮВАННЯ СИСТЕМИ МОНІТОРИНГУ РИЗИКІВ НА ТРАНСПОРТІ}

У статті розглядаються актуальні проблеми моделювання процесів моніторингу ризиків на транспорті. Такий моніторинг передбачає визначення стану транспортних об'єктів, а також прочедури мінімізаиії наслідків ситуачій, викликаних настанням ризиків.

У статті розглядаються проблеми ефективного створення системи моніторингу ризиків на транспорті на основі використання відповідних моделей. У статті пропонується моделювати систему моніторингу на основі ситуачійно-семантичної моделі. Запропонований підхід буде сприяти визнанню ризиків і формування управлінських рімень щодо усунення їх наслідків. Запропонована ситуачійно-семантична модель дозволяє: прогнозувати поведінку складних транспортних об'єктів та об'єктів транспортної інфраструктури; враховувати можливість появи нових транспортних об'єктів і процесів для забезпечення їх функиіонування в умовах мінімізачії можливих ризиків; адекватно реагувати на локальні і глобальні фактори впливу на транспортні об'єкти; динамічно змінювати структуру системи; враховувати нові дані для прогнозування розвитку $i$ вдосконалення відповідних транспортних об'єктів; прогнозувати розвиток процесів, що забезпечують мінімізацію ризиків та їх наслідків.

Ключові слова: модель, моделювання, інформаційна система, ризики на транспорті, моніторинг проиесів, семантичні мережі, ситуачійно-семантичні мережі. 